\title{
抗菌性に優れる $\mathrm{Ag}$ 微細分散型ステンレス鋼 (リバーライト $\mathrm{AB}$ シリーズ)の開発
}

\author{
横田 毅* 栃原美佐子炎 高 尾 研 治当 \\ 佐藤進亦 山下英明娄
}

\section{1. は じめに}

1996年飞発生した病原性大腸菌 O-157 による集団感染以 来, 消費者の間で食品に対する安全衛生への意識が急速に高 まった。ささら 2000 年に入って黄色ブドウ球菌による食中 毒の発生やMRSA(メチリシン耐性黄色ブドウ球菌)による 院内感染が頻発し, 企業や病院の衛生管理体制に対しても人 々の関心が注がれている。こうした社会的情勢を受け, 衛生 陶器, プラスチックさらには衣料品に至るまで様々な分野で 抗菌製品(1)-(3)が開発されている(ここで抗菌とは細菌の増殖 を抑制することと定義され，殺菌とは区別されている)，一 方，ステンレス鋼は良好な耐食性と表面の清潔感などから的 房や食品工場など衛生管理を必要とする場所で積極的に利用 されてはいるが，一般のステンレス鋼に抗菌性は認められな い(4). ステンレス鋼の場合, 他の抗菌製品のよ5に抗菌剂を 含有する皮膜をコーティングする方法(2)では, 研磨加工やプ レス加工さらには日常の清掃等で表面の抗菌化層が剥離し抗 菌性が低下寸るら兄, ステンレス本来の金属光沢が失われる 危険性がある. また，大量の抗菌元素を添加して抗菌性を確 保しようとすると，耐食性が低下する。そこで，著者らは抗 菌性を付与したら壳で, 人体に安全かつ従来の耐食性, 金属 光沢を維持したステンレス鋼の開発に取り組んだ。そして, 世界で初めて銀添加着目乙抗菌性と耐食性をあわせもつス

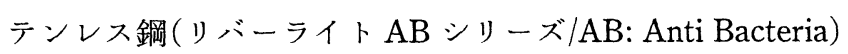
の開発に成功した.

\footnotetext{
* 川崎製鉄株式会社

技術研究所ステンレス鋼研究部門 : 1)主任研究員

技術研究所分析物性研究部門: 2) 部門長

千葉製鉄所商品技術部ステンレス管理室 : 3) 室長

Development of Silver Bearing Stainless Steels with Anti-bacteria Activity.; Takeshi Yokota, Misako Tochihara, Kenji Takao, Susumu Satoh, Hideaki Yamashita (Kawasaki Steel Corporation)

2000 年 10 月 30 日受理
}

\section{2. 開 発 経 緯}

抗菌ステンレス鋼の要求特性として, 以下の 3 つの項目 があげられる。

(1) 抗菌性：JIS で定められた抗菌試験方法 ${ }^{(5)}$ そおいて, 次式で定義される減菌率が99\%以上あること.

減菌率 $(\%)=100 \times($ 比較鋼の生菌数一開発鋼の生菌数 $) /$ 比較鋼の生菌数

な扮，抗菌効果は抗菌製品上の 24 時間後の生菌数が比較 製品上の生菌数の $1 \%$ 以下と定義されているため, 減菌率 99\%以上を抗菌効果発現の基準値として採用した.

（2）耐食性：Ag を添加していない同種のステンレス鋼と 同等の耐食性を有すること

（3）その他：金属光沢など従来と同等の表面性状を有する こと

抗菌ステンレス鋼の開発に当たってもっとも重要となった のは, 抗菌性を発現させるために添加する元素の選定であ る. 抗菌性は材料の表面から溶出した金属イオンが, 細菌中 の呼吸をつかさどる酵素の $\mathrm{SH}$ 基と反応し, 細菌の代謝を阻 害寸ることにより発現すると考光られている(6)(7)。したがっ て，ステンレス鋼の場合にも抗菌作用のある金属元素を添加 し抗菌性を発現させるためには，鋼板表面から金属イオンが 溶出することが必要となる。一方で金属イオンの溶出部分で は不動態皮膜の破壊または劣化が生じるため, 耐食性が低下 する可能性がある。したがって，抗菌性と耐食性を両立させ るためには, 抗菌力の強いしか子安全性の高い元素を微量に 添加し，かつ鋼板中に微細・均一飞分散させる必要がある.

\section{（1）各種金属イオンの抗菌力}

抗菌性に有効とされる $\mathrm{Ag}, \mathrm{Cu}$ 扮よび $\mathrm{Ni}$ の 3 種類の金属 イオンの抗菌力をシェークフラスコ法年炕より比較した。実 験は, $1 / 500$ 普通ブイヨン倍地(精製水 $1000 \mathrm{~mL}$ 亿肉エキス $5.0 \mathrm{~g}$, 塩化ナトリュウム $5.0 \mathrm{~g}$, ペプトン $10.0 \mathrm{~g}$ を溶かし, 


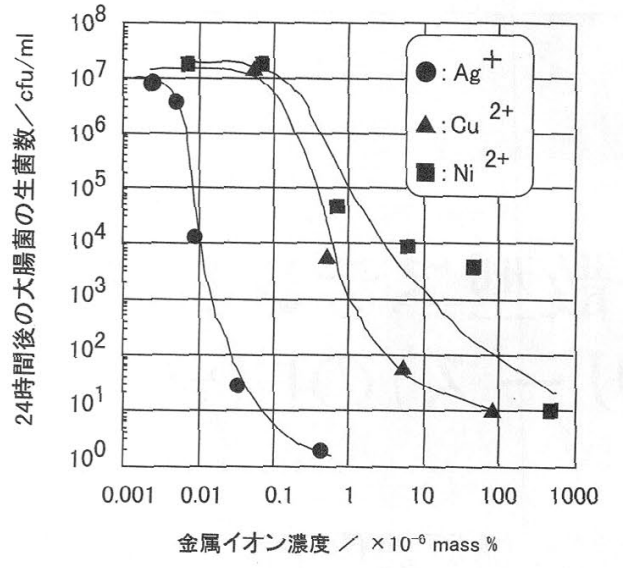

図 1 振激培養後の大腸菌の生菌数に打よぼす金属イ オン濃度の影響.

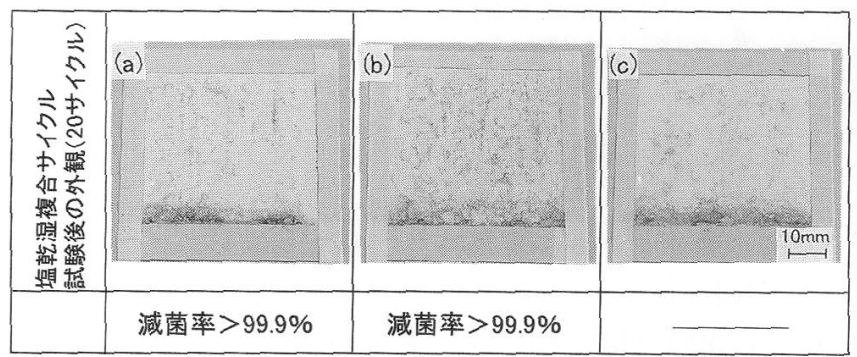

図2 SUS304 鋼の抗菌性抎よび耐食性に特よぼす Ag 添加量の影響.
(a) $\mathrm{Ag}=0.041$ mass $\%$, (b) $\mathrm{Ag}=0.080$ mass $\%$,
(c) 比較鋼 (SUS304).

$\mathrm{pH}$ を7.0〜 7.2 亿調整した溶液)で大腸菌濃度が約 $10^{7} \mathrm{cfu} /$ $\mathrm{mL}$ (cfu: colony forming unit)となるように調整した試験菌 液 $(15 \mathrm{~mL})$ に各種金属イオンを添加し24時間振盪培責する方 法で行われた．24時間後の大腸菌の生菌数と添加した金属 イオン濃度の関係を図 1 亿示す. JIS の抗菌試験方法と同様 の基準で評価すると，24時間後の生菌数が $10^{4} \mathrm{cfu} / \mathrm{mL}$ 以下 となれば抗菌効果発現と判定される。抗菌効果が発現する金 属イオン濃度はAgイオンが $1 \times 10^{-8}$ mass\%であるのに 対して，Cuイオン $1 \times 10^{-6}$ mass $\%, \mathrm{Ni}$ オン $8 \times 10^{-6}$ mass\%である。すなわち mass\%で比較すると $\mathrm{Ag}$ イオンは $\mathrm{Cu}$ イオンの䄪100倍, Niイオンの約 800 倍の抗菌力を有す ると結論できる。

\section{（2）抗菌性および耐食性におよぼす $\mathbf{A g}$ 添加量の影響}

SUS304 相当成分鋼に Ag を添加し，抗菌性打よび耐食性 への影響を調べた。な牧, 而食性は, 塩乾湿複合サイクル試 験(20サイリル)により評価した。実験の結果を図 2 に示す。 $\mathrm{Ag}$ 添加鋼はともに減菌率 $99.9 \%$ 以上の抗菌性を有する。一 方，耐食性に関しては， 0.041 mass\% Ag 添加鋼は比較鋼 (SUS304) 々同等の耐食性を示すが， 0.080 mass \% Ag 添加 鋼は，比較鋼 (SUS304) 飞比べて耐食性が低下する。

\section{(3) Ag の微細分散状態}

$\mathrm{Ag}$ 添加 SUS304 (表面仕上げ：2B)の表層执よび $2 \mu \mathrm{m}$ 研
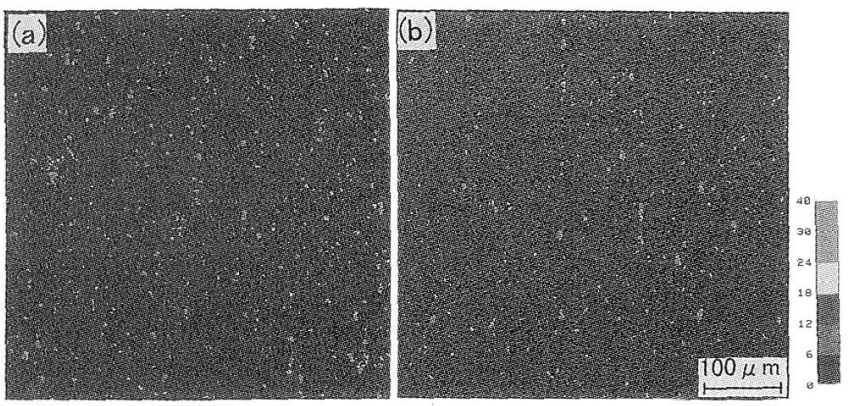

図 $3 \mathrm{Ag}$ 添加ステンレス鋼中の $\mathrm{Ag}$ の分布.

（a）表層，(b) 表層を $2 \mu \mathrm{m}$ 研磨.

表 1 開発鋼の化学組成の代表例(mass\%).

\begin{tabular}{lcccccccc}
\hline \multicolumn{1}{c}{ 開発鋼 } & $\mathrm{C}$ & $\mathrm{Si}$ & $\mathrm{Mn}$ & $\mathrm{P}$ & $\mathrm{Cr}$ & $\mathrm{Ni}$ & $\mathrm{Ag}$ \\
\hline $\begin{array}{l}\mathrm{Ag} \text { 添加 SUSS304 } \\
(\mathrm{R} 304-\mathrm{AB})\end{array}$ & 0.05 & 0.30 & 1.00 & 0.03 & 18.2 & 8.1 & 0.042 \\
\hline $\begin{array}{l}\mathrm{Ag} \text { 添加 SUS430 } \\
(\mathrm{R} 430-\mathrm{AB})\end{array}$ & 0.06 & 0.25 & 0.65 & 0.03 & 16.2 & - & 0.039 \\
\hline $\begin{array}{l}\mathrm{Ag} \text { 添加 SUS430LX } \\
(\mathrm{R} 430 \mathrm{LN}-\mathrm{AB})\end{array}$ & 0.01 & 0.25 & 0.45 & 0.03 & 17.7 & - & 0.040 \\
\hline
\end{tabular}

磨後の $\mathrm{Ag}$ の分布状態を電子線マイクロアナライザーにより 調查した結果を図 3 に示す。表層牤よび内部ともに $\mathrm{Ag}$ が微 細かつ均一に分散していることが分かる. 研磨後も抗菌性を 発現させるためには，このように内部本で $\mathrm{Ag}$ 走均一に分散 させる技術が必要不可欠となる。

以上の結果泇光, $\mathrm{Ag}$ の人体への安全性(7), 製造コス ト，製造性を考慮してステンレス鋼の $\mathrm{Ag}$ 添加量を決定した。

\section{3. 開発鋼の特性}

現在，当社で製造・販売している開発鋼の化学組成を表 1 に示す。をた, 開発鋼の特性をR304-AB(Ag 添加 SUS304, 表面仕上げ: 2B)を例にとって以下に紹介する.

\section{(1) 抗菌性}

\section{(a) 公的機関での抗菌試験結果}

開発鋼 $(\mathrm{R} 304-\mathrm{AB})$ ) 公的機関 (社団法人日本食品衛生協会) での抗菌試験結果を図 4 亿, 抗菌試験後の生菌数の観察例圭 図 5 に示す。開発鋼は大腸菌や黄色ブドウ球菌に対してだけ でなく病原性大腸菌 O-157 や院内感染の原因となる MRSA に対しても抗菌効果を発揮する。すなわ出，24時間後の生 菌数は，いずれの細菌に対しても $10 \mathrm{cfu} /$ 枚以下となる。さ ら火, 開発鋼の表面をエメリ一研磨紙で $2 \mu \mathrm{m}$ 研磨後, 大腸 菌に対する抗菌性を調べた結果，抗菌性は全く低下しないこ とがわかった。

\section{(b) 抗菌効果におよぼす試験時間の影響}

抗菌効果に打よぼす試験時間(菌液接種後の培養時間)の影 響を図 6 亿示与，大腸菌を例にとった場合，菌液接種後 1 時間で生菌数の減少が確認され，3 時間後には減菌率は99\% 


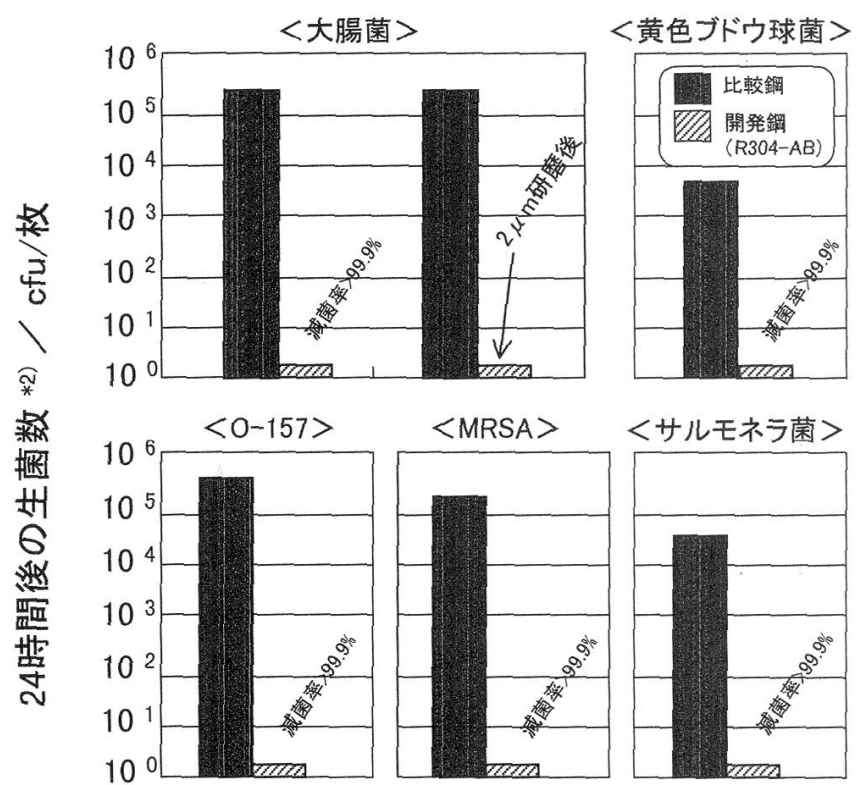

図 4 開発鋼 (R304-AB) 打よび比較鋼(SUS304)の各 種の細菌に対する抗菌性*1).

*1) 試験依頼先 : 社団法人日本食品衛生協会 試験報告書発行日：1999年12月 2 日， 2000年 5 月 9 日

試験検查成績書番号 : 第91-5155号,

*2) $n=3$ の平均值. 第01-2172号.

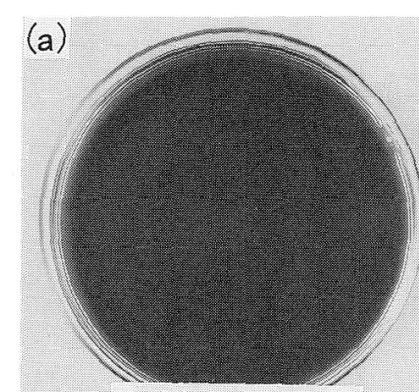

生菌数 $<10 \mathrm{cfu} /$ 枚 (b)

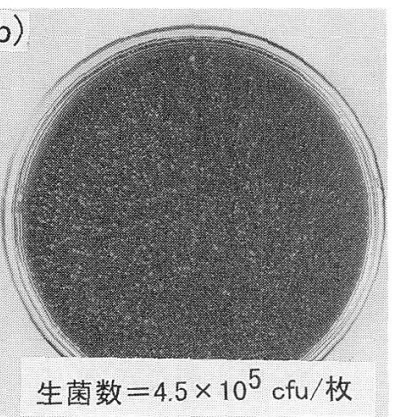

図 524 時間後の生菌数確認結果(O-157 での試験例). (a) 開発鋼 (R304-AB)，(b) 比較鋼 (SUS304).

以上となる。

\section{（2）耐食性}

耐食性を評価するため塩乾湿複合サイクル試験を10サ イクル行った．試験後の鋼板の外観を図７に示す．開発鋼 (R304-AB) は比較鋼(SUS304) と同等の耐食性を示すこと が明らかとなった。

\section{4. 開発鋼の適用例と工業所有権}

開発鋼は，1998年に世界で初めて Agを添加した抗菌ス テンレス鋼として発売され, 洗濯槽, 洋食器扣よび厨房用品

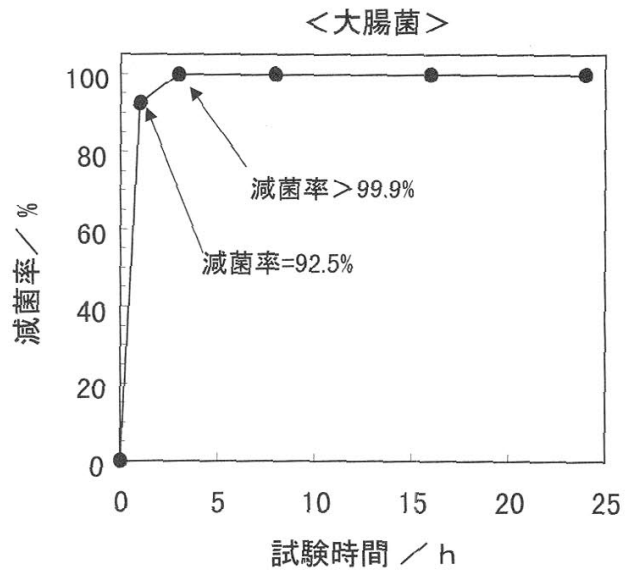

図 6 開発鋼 $(\mathrm{R} 304-\mathrm{AB})$ の抗菌効果発現に打上ぼす試 験時間の影響.
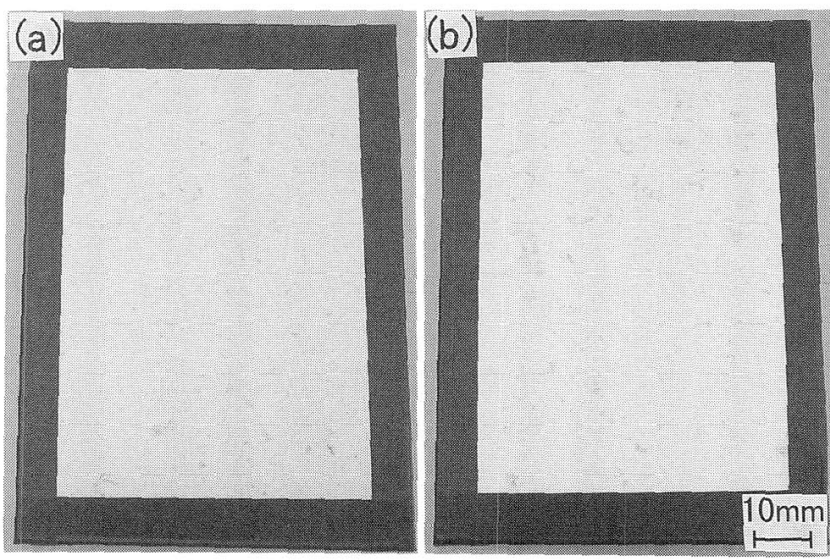

図 7 塩乾湿複合サイクル腐食試験の外観(10サイクル). (a) 開発鋼 (R304-AB), (b) 比較鋼 (SUS304). 1 サイクル: 3.5 mass $\% \mathrm{NaCl}\left(35^{\circ} \mathrm{C}, 0.5 \mathrm{~h}\right) \rightarrow$ 乾燥 $\left(60^{\circ} \mathrm{C}, 1 \mathrm{~h}\right) \rightarrow$ 湿潤(湿度 $\left.\geqq 95 \%, 1 \mathrm{~h}\right)$

などに適用されている. 今後も社会的なニーズを受け, 衛生 管理を必要と寸る分野での使用桩大が期待される。

開発鋼に関わる特許は国内 13 件, 国外 3 件の特許が出願 済みである。

\section{文献}

（1）ダイヤモンド経営開発情報 R \& D トピックス抗菌塗料：ダイ ヤモンド社, (1998), 1-16.

（2）西村民男：抗菌の基礎知識，株式会社テクノシステム, (1999), pp. 197-252.

（3）西村民男：防菌防徽ハンドブック，技報堂出版，(1986）.

（4）中村定幸，大久保直人，宮楠克久，長谷川守引植居義雄： 日新製鋼技報， 76(1997), pp. 48-56.

（5）日本規格協会：抗菌加工製品一抗菌性試験力法・抗菌効果 JIS Z 2801 (2000)

（6）Kul'skii, L. A.: 銀イオン水，日ソ通信社，(1987).

（7）大谷朝男：多様化する無機采抗菌剤と高度利用技術, 侏式会 社アイピーシー, (1997).

（8）中島照夫：防菌防徽，16(1988)，249-260. 